\title{
【シンポジウム 2】
}

\section{身体活動ガイドライン改定の方向性と内容 \\ 身体活動基準改定レビュー班の取り組み \\ （+10のエビデンス補強のため文献レビュー）}

\author{
丸藤祐子 ${ }^{1}$, 川上 諒子 ${ }^{2}$, 宮地元 彦 $^{2}$, 澤 田 亨 $^{2}$ \\ ( ${ }^{1}$ 駿河台大学, ${ }^{2}$ 早稲田大学)
}

この研究班では, 現在の「健康づくりのための身体活 動基準/指針2013」における，身体活動量を少しでも増 やすことの重要性を示した「+10（プラス・テン）から 始めよう！」に関するエビデンスを補強することを目的 とし, 身体活動と疾病/死亡リスクに関する「量反応関 係」（身体活動量が増えるほど, 疾病/死亡リスクがより 減っていく関係）に主眼を置いた文献レビューを行っ ている。文献レビューでは, トップジャーナル（Ann Intern Med, BMJ, JAMA, Lancet, N Engl J Med）に限 定し，質の高いエビデンスを集めることとした，質の高 いエビデンスを積み上げることで, 身体活動の重要性を 際立たせ，次の基準/指針の策定および普及/啓発をす る際にサポートできるのではないかと考えている.

文献収集では，身体活動と疾病/死亡リスクに関する コホート研究について，5誌に限定した文献収集を 2 通 りの方法で行った，1つ目として，現在の「健康づくり のための身体活動基準2013」における文献データベース から該当論文を抽出した，2つ目として，それ以降に公 表されている論文については，文献検索を実施した。集 められた論文から, 量反応関係のメ夕解析が可能な論文 を抽出し，2つのメ夕解析を実施した. 1つ目に，総
身体活動量と疾病/死亡リスクとの間の線形量反応メ夕 解析を実施し，+10分で何\%のリスク低下が見达めるの か？を分析した。この結果では，+10分で約 $3 \%$ のス ク低下が見込めるという結果が示唆された。 2 目に, 総身体活動量と疾病/死亡リスクとの間の非線形量反応 メ夕解析を実施し, 量反応関係は線形か非線形の関連を 示すのかを分析した。ささらに, 非線形の関係だった場合, どのような曲線が描かれるかを確認した。 この結果では, 非線形の量反応関係があることが示され，身体活動レベ ルの増加が低い場合でも，リスクが低下している曲線が 確認された。

今回のシンポジウムでは, 本研究班の取り組みとし て, アクティブガイドにおける重要なメッセージである $\lceil+10$ (プラス・テン)」をより多くの質の高いエビデン スによって補強するためのレビューを実施し，プラス． テンを支持する多くの研究が確認できたことを報告し た. 文献レビューとメ夕解析の結果,「プラス・テン」 によって疾病・死亡リスクが $3 \%$ 低下すると推定され, 身体活動基準2013でのエビデンスと同様の傾向であった ことも確認された。 